\title{
Assessing Payment for Ecosystem Services of Panchase Conservation Area: Exploring the Potentialities ${ }^{1}$ Muna Sharma, ${ }^{2,3}$ Suman Bhattarai, ${ }^{4}$ Shivaraj Thapa, ${ }^{2}$ Bharat Panthi, ${ }^{2}$ Hom Bahadur Chhetri, ${ }^{2,3^{*}}$ Deepak Gautam \\ ${ }^{1}$ Division Forest Office, Gulmi, Department of Forest, Government of Nepal \\ ${ }^{2}$ Institute of Forestry, Tribhuvan University, Pokhara, Nepal \\ ${ }^{3}$ Beijing Forestry University, Beijing, China \\ ${ }^{4}$ Environment Resource Management (ERM), Nepal \\ *Corresponding author: deepakgautamiof@gmail.com
}

Article History

Received 7 May 2021

Revised 19 September 2021

Accepted 13 November 2021

\begin{abstract}
Adoption of "Payment for Environmental Services (PES)" scheme can be one option to protect the forest area and the Phewa Lake for sustaining the existing benefits. The study was carried out to explore the adoption possibility of PES mechanism in Panchase Conservation Area (PCA) for the sustainable management of the forest and the Phewa Lake. The study was focused on people of Bhadaure and Chapakot villages of Panchase area as upstream dwellers and different downstream communities benefitted from the lake. Major environmental services were prioritized for both upstream and downstream dwellers and the major impacts on the downstream communities were also found out. Multiple linear regression model was adopted to assess the factors affecting the downstream communities for providing suitable incentives to upstream dwellers. Watershed protection was found to be the major environmental service prioritized by both upstream and downstream respondents. Most of the people of both upstream and downstream communities are willing to accept (WTA) and pay (WTP) for the protection of the prioritized environmental service. Hotel communities were seem to have highest WTP followed by boating, fishing and agricultural communities. Also, Income, education, household member and residential distance were statistically significant to WTP of downstream beneficiary group. Based on the WTP of the downstream beneficiary groups, it is concluded that the area is potential for initiating PES mechanism for the sustainable
\end{abstract}

(C) The Author, published by JRCC, Janapriya Multiple Campus. 
conservation of watershed and regulate benefits on sustained basis. Education based activities should be organized to enhance participation of more beneficiaries and upstream dwellers whereas proper policy mechanism should be formulated for assuring community people before the implementation of PES.

Keywords: Downstream, payment for ecosystem services, upstream, watershed protection, willingness to pay, willingness to accept

\section{INTRODUCTION}

Ecosystem Services is defined as 'the benefits that people obtain from ecosystems'. Ecosystem provides a wide range of goods and environmental services that are demonstrably beneficial to human kind Millennium ecosystem assessment (MEA, 2005). Ecosystem services include provisioning services (food, water, and timber), regulating services (climate, diseases, wastes and water quality), supporting services (soil formation, photosynthesis and nutrient cycling) and cultural services (recreational, aesthetic and spiritual benefit) (Costanza et al., 1997; Costanza et al., 2014; MEA, 2005). The contribution and the sharing mechanism of environmental services doesn't always match among all the stakeholders leading to a freeriding problem (Fisher et al., 2009). Different degree of contribution if not adjusted with the benefit sharing resulted in devaluation of the services in one part and lack of the motivation for conservation in another part (Bhatta et al., 2014). This problem which has been increasingly recognized in recent years is leading to the degradation of the ecosystem (Aryal et al., 2019; Poudyal et al., 2018; Thapa et al., 2021). This led to the development of new systems as alternatives to past approaches and among all, one of the more recent approaches is the one that promotes Payment for Ecosystem Services (Aryal et al., 2019).

PCA provides a range of environmental goods and services (Bhandari et al., 2018). Among all, hydrological services from Phewa Lake is one of the major environmental service provided by PCA (Paudel \& Khanal, 2012). Phewa Lake is one of the tourism attractions with the availability of all the goods and services needed for the tourist. Phewa Lake not only provides the tourism flow but also helps different local communities by providing various direct as well as indirect benefits from the lake (Poudyal et al., 2018).

But at the meantime, the lake area has been reducing significantly due to various reasons. Japan International Cooperation Agency (JICA) carried a time series map analysis in 1998 and stated that the lake area has been decreased from $10 \mathrm{~km}^{2}$ in $1956 / 57$ to $5.5 \mathrm{~km}^{2}$ in 1976 and 
$4.4 \mathrm{~km}^{2}$ in 1998. At present the lake area is about $4.2 \mathrm{~km}^{2}$ (Vuillez et al., 2018). The above circumstances can result in the life span of Phewa watershed up to 2150 B.S (Maskey, 2010). Study shows that Phewa watershed was undergone various natural land formation process and it has further degraded due to unplanned terrace cultivation, over grazing, deforestation and developmental works (Poudyal et al., 2017; Vuillez et al., 2018) .

Conservation of the Phewa watershed is a prime issue for the income generation by various beneficiary communities (Gurung et al., 2005; Poudyal et al., 2017). To minimize the negative impacts, conservation steps should be taken from the source point i.e PCA. If the forest is conserved and protected, it will stop erosion and will generate pure water to the Harpan khola, the main feeder stream of the lake, and from which the water quality as well as quantity can be maintained in Phewa Lake. Potentiality assessment of Payment of ecosystem services in Phewa watershed helps to get the idea about the highly prioritized environmental services that people gain and the feasibility of the PES implementation. Thus, the study aims to explore the potential of Payment for Ecosystem Services (major hydrological services) in the PCA.

\section{DATA AND METHODS}

The PCA was gazetted as a 'Protected Forest', under the article 23 of the Forest Act 2002 by recognizing its rich biodiversity, forest resources as well as cultural and spiritual values on 27 February 2011 (Suwal et al., 2013). The Panchase Protected forest covers 5,775.73-hectare area in 9 villages. Annapurna Rural Municipality (ARM) ward no. 4 (Bhadure village). is the major source point of Harpan khola (river). The Lake is semi-natural freshwater in subtropical mountain climate lying at the Pokhara Valley $\left(2807^{\prime}-28012^{\prime} \mathrm{N}, 8407^{\prime}-84019^{\prime} \mathrm{E}\right)$ that falls on a relative subsidence zone in between the Greater Himalaya and the Mahabharat Range. It has recorded 589 species of flowering plants including 107 medicinal and aromatic plants and 113 orchids, 56 species of wild mushrooms, and 98 species of ferns in this region (DOF, 2012). The study area represents five forest types i.e. alder forest, chirpine-broad leaved forest, oaklaurel forest, lower temperate oak forest, and Schima-Castonopsis forest (DOF, 2012). PCA provides a range of environmental goods and services. In order to conserve these ecosystem services and sustain income generation activities of this area, it is crucial to promote PES mechanism. This shows the necessity to measure the possibility of PES mechanism for the sustainable development of ecosystem of PPF.

Prior to data collection, the oral consents were acquired from participating households 
and stakeholders. The determination of Sampling procedure, Sample size and Data collection was done after consultation with experts and academicians and with due consideration to the limitations of time, budget, and human resources. This study was based on the questionnaire survey, key informant interview (KII) and focus group discussion (FDG).

The questionnaire was divided into the following three parts. The first consisted of demographic and socio-economic characteristics, which included the respondent's age, gender, education, work type, distance from the lake, household size and income. This part of the questionnaire explored explanatory variables of the respondent's willingness to pay and the forest manager's willingness to accept. The second part included questions related to information about respondent's perceptions on concept of payment for environmental services. The third part of the questionnaire included the information related to factor affecting willingness to pay.

We considered people living in Bhadaure village (Annapurna Rural Municipality ward no.4) and Chapakot village (Pokhara Metropolitan Ward no 23) were categorized as upstream community as the area is a source point of feeder stream for Phewa Lake. We selected 30 households from each village. Whereas people living close to the lake on the eastern and southern side of the lake who were directly involved in making benefits from the lake. Four communities as a downstream beneficiary groups such as Hotel, Fishing, Boating and Agricultural communities were selected and 15 respondents in each communities were interviewed for the household survey.

The survey was administered through face-to-face questionnaire. In total, 120 respondents were selected for household survey, out of which 60 respondents were from upstream land managers and 60 respondents were from downstream beneficiaries. The household head was selected for the interview. Each Household from upstream and downstream communities were sampled using transact survey procedure where the main road was assigned as survey route and household near to the road were surveyed till 60 households were completed.

Similarly, we conducted key informant interview using structured and semi structured questionnaire. In total, 15 key informant interview was designed with the executive members of CFUG, key government officials and the local leaders in order to get the relevant information from the local people. Likewise, one Focus Group Discussion (FGD) was organized with various levels of stakeholders in the study area to supplement and triangulated the information gathered from other sources.

Multiple linear regression model was designed to determine factors influencing the 
respondent's willingness to pay. To do that willingness to pay was used as a dependent variable. The socio-economic factor considered in this study include income, education, age, time of residency, distance form lake, and household member.

$$
W T P=\beta_{0}+\beta_{1} X_{1}+\beta_{2} X_{2}+\beta_{3} X_{3}+\beta_{4} X_{4}+\beta_{5} X_{5}+\beta_{6} X_{6}+\varepsilon \ldots \ldots \ldots \ldots \ldots \ldots \ldots \text { (1) }
$$

Where WTP is a willingness to pay of an individual respondent, $\beta_{0}$ is an intercept, $\beta_{1}$, $\beta_{2}$ up to $\beta_{6}$ are the estimated parameters of all explanatory variables, $\mathrm{X}_{1}-\mathrm{X}_{6}$ include (household monthly income, education of the respondents, age of the respondents, time of residency of the respondent, distance from the lake and household size) and is the error term.

Explanatory variables were selected through the literature review and used to explain the variability in the dependent variables (Table 1). Before running multiple linear regression, necessary assumptions such as perfect collinearity, zero conditional mean, and heteroscedasticity problems were checked. Perfect collinearity among all independent variables were checked using correlation and covariance in order to avoid possible co-linearity. Respondents working year for environment conservation have a perfect correlation with time of residency of respondents. So it dropped from the model. Similarly, zero conditional mean assumptions was tested by regressing residuals on all independent variables and check any explanatory variables that have statistically significant relation at 5\% significance level with other variables that are not included in the model. Heteroscedasticity problem was also checked using the Breusch and Pagan (1979) test. Additionally, descriptive statistics tools like bar graphs, scatter graphs, means, proportion, and frequency was also used to illustrate the results. Household characteristics are key factors since they influence decision-making as whether or not to pay. WTP of respondents in PPF conservation programs may vary according to their socio-economic and demographic backgrounds, such as household income, household size, educational level, age, land tenure status (Zhou \& Li 2015). A brief description of each explanatory variable and the expected theoretical relationship to forest dependency is provided hereunder.

\section{Table 1}

Explanation and Summary of Variables Used in Multiple Linear Regression Model

\begin{tabular}{lll}
\hline Variables & Expected Sign & Description \\
\hline Income & + & Monthly income of household \\
Education & + & Education of respondents \\
Age & + & Age of household head in year \\
Time & + & Time of residency of the respondent \\
\hline
\end{tabular}




\begin{tabular}{lll}
\hline Distance & + & $\begin{array}{l}\text { Distance of Lake from the respondent's } \\
\text { home }\end{array}$ \\
Household member & $? ?$ & Number of people in a family \\
\hline
\end{tabular}

\section{RESULTS AND DISCUSSION}

\section{Selected Background Characteristics of Respondent}

Among the total respondents, more than $60 \%$ are male in both communities. Mostly, the working group people (20-40) were chosen for the questionnaire. Furthermore, 55\% of respondents have more than 3 members in their family. Similarly, the result showed that $70 \%$ had attained primary school and the remaining $30 \%$ had attained higher education.

In addition, majority of downstream respondents were engaged in tourism business (fishing, boating, hotel services, and tour operators) whereas, majority of respondents from upstream were engaged in agriculture, daily wages, and other business. The annual household income of $40 \%$ of respondents was distributed at about US\$110 - US\$200 at both communities.

Table 2

Summary of Demographic Profile of Sample Respondents $(n=120)$

\begin{tabular}{llll}
\hline Variables & Categories & $\begin{array}{l}\text { Percentage } \\
\text { Upstream land } \\
\text { managers }\end{array}$ & $\begin{array}{l}\text { Downstream } \\
\text { beneficiaries }\end{array}$ \\
\hline Sex & Male & 61.7 & 65 \\
Ethnicity & Female & 38.3 & 35 \\
& Brahmin/Chhetri & 53.3 & 45 \\
& Janajati & 18.3 & 26.7 \\
Age (in years) & Dalit & 28.3 & 28.3 \\
& $20-40$ & 45.2 & 51.7 \\
Household Size (Number) & $1-2$ & 33.6 & 35 \\
& $40-60$ & 21.2 & 13.3 \\
& $60+$ & 11.7 & 6.7 \\
& $3-6$ & 55.2 & 75 \\
& $7-10$ & 23.1 & 10.3 \\
\hline
\end{tabular}




\begin{tabular}{llll}
\hline Time of Residency(in years) & $0-15$ & 5 & 30 \\
& $16-30$ & 26.6 & 38.3 \\
& $31-45$ & 3.3 & 10 \\
& Permanent & 65 & 21.7 \\
Monthly Income (NRs) & $0-10,000$ & 38.3 & 10.3 \\
& $11,000-20,000$ & 43.3 & 40 \\
& $21,000-40,000$ & 18.3 & 24.7 \\
& $41,000-70,000$ & 0 & 15 \\
& Above 71,000 & 0 & 10 \\
Time to reach to the forest & $1-15$ & 30.6 & 35 \\
for upstream and lake for & $16-30$ & 55.3 & 46.7 \\
downstream respondents & $30-60$ & 18.3 & 14.1 \\
\hline
\end{tabular}

\section{Prioritization of Environmental Services}

When asked about the peoples' perception on the most important environment services (ES) provided by the Phewa Lake, Clean and silt less water was found to be one of the top most prioritized ES. The same environmental service was in the top most rank (Maskey, 2010; Paudel et al., 2012). This illustrates that the downstream communities' focuses on the Watershed Protection, as the degraded quality and quantity of the lake water is hampering the people since almost all the communities are directly or indirectly sustaining their livelihoods from the lake.

Table 3

Prioritization of Environment Services by Both Land Managers and Downstream Beneficiaries

\begin{tabular}{|c|c|c|c|c|c|c|c|c|}
\hline \multirow{2}{*}{$\begin{array}{l}\text { Environmental } \\
\text { services } \\
\text { Rank }\end{array}$} & \multicolumn{2}{|c|}{$\begin{array}{l}\text { Clean and silt } \\
\text { less water flow }\end{array}$} & \multicolumn{2}{|c|}{$\begin{array}{l}\text { Fresh } \\
\text { Environment }\end{array}$} & \multicolumn{2}{|c|}{ Biodiversity } & \multicolumn{2}{|c|}{$\begin{array}{l}\text { Beautiful } \\
\text { Landscape }\end{array}$} \\
\hline & $\mathrm{U}$ & $\mathrm{D}$ & $\mathrm{U}$ & $\mathrm{D}$ & $\mathrm{U}$ & $\mathrm{D}$ & $\mathrm{U}$ & $\mathrm{D}$ \\
\hline First & 36 & 38 & 30 & 16 & 3 & 6 & 7 & 7 \\
\hline Second & 12 & 14 & 14 & 29 & 7 & 10 & 6 & 13 \\
\hline Third & 7 & 5 & 10 & 9 & 15 & 33 & 32 & 18 \\
\hline Fourth & 3 & 3 & 5 & 6 & 30 & 11 & 15 & 22 \\
\hline Undecided & 2 & - & 1 & - & 5 & - & - & - \\
\hline Total & 60 & 60 & 60 & 60 & 60 & 60 & 60 & 60 \\
\hline
\end{tabular}

Note: $\mathrm{U}=$ Upstream land manager, $\mathrm{D}=$ Downstream beneficiaries 


\section{Major Impacts on Phewa Lake}

During the survey, the respondents were asked to state the types of impacts on downstream that they were facing due to destruction of natural resources. They were also asked to state their perception on statements in relation to impacts they were facing with Likert Scale technique. From Likert Scale, the respondents stated their level of perception form scale of 1 (very high impact) to 7 (least impact). Majority of the downstream respondents are in consensus on, occurrence of natural disasters and secondly disappearance of lake due to sedimentation which are mainly caused by the improper agricultural practices. The respondent feel the immediate need of proper management of watershed as soon as possible because if the rate of sedimentation increases in the same rate as it is of today, then we will no longer be able to see the lake in the very near future. This will even affect the tourism industry resulting in the loss of employment opportunity.

More impact on people due to natural disaster and sedimentation problem can be the reason why people prioritize watershed protection as major environmental service (Table 4).

\section{Table 4}

Major Impacts on Downstream Beneficiaries Based on Respondents

\begin{tabular}{llllll}
\hline S.N & Effect & Min & Max & Mean & S.D \\
\hline 1 & $\begin{array}{l}\text { Natural disaster(risk of flood, landslide } \\
\text { and soil erosion) }\end{array}$ & 1.00 & 3.00 & 1.5667 & 0.721 \\
2 & $\begin{array}{l}\text { Disappearance of Phewa lake in } \\
\text { future caused by sedimentation }\end{array}$ & 1.00 & 3.00 & 1.6000 & 0.527 \\
$\quad \begin{array}{l}\text { Unavailable of water for } \\
\text { irrigation and hydropower }\end{array}$ & 3.00 & 7.00 & 4.9167 & 1.305 \\
& $\begin{array}{l}\text { Obstacles in tourism industry and } \\
\text { loss of employment }\end{array}$ & 1.00 & 5.00 & 3.3667 & 0.882 \\
6 & $\begin{array}{l}\text { Unavailable of water for boating } \\
7\end{array}$ & 2.00 & 6.00 & 4.2333 & 0.927 \\
\hline
\end{tabular}

WTP by Downstream Communities and WTA by Upstream Communities

Regarding the issues on willingness to pay for the compensation by downstream beneficiaries for the longitivity of the prioritized environmental services, about $65 \%$ of the respondents are willing to pay the compensation, whereas $13.3 \%$ of the respondents are not 
ready to pay the compensation. The result revealed that about two-third of the respondents is willing to accept the PES mechanism. 13\% of the respondents are not willing to accept any kind of PES mechanism whereas nominal respondents (only 4\% of respondents) said that they don't want any type of compensations as they are self-motivated and are ready to do the management activities by themselves.

\section{Willingness to Pay on the Basis of Income}

Among all the respondents who want to pay the compensation, about half of the respondents are willing to pay $1 \%$ of their income as compensation. $21.7 \%$ of the respondents are willing to pay $0.5 \%$ of their income whereas nominal respondents are willing to pay $2 \%$ of their earning. $18.7 \%$ of the respondents are not willing to pay the monetary compensation. Instead they are willing to compensate by other means (voluntary, agreement etc.). The opinions seem to be a milestone for the development of PES mechanism.

\section{Table 5}

Willingness to Pay of Sample Household in Four Strata of Begnas Watershed System for Conservation and Sustainable Management

\begin{tabular}{ll}
\hline Community wise WTP & Average Amount household ${ }^{-1}$ month $^{-1}(\mathrm{NRs})$ \\
\hline Hotel communities & 355 \\
Fishing communities & 76.4 \\
Boating communities & 98.3 \\
Agricultural communities & 34 \\
\hline
\end{tabular}

\section{Factors Influencing the Willingness to Pay to the Downstream Beneficiaries}

The model is statistically significant at $5 \%$ significance level. In terms of individual significance of the explanatory variable, time of residency, lake based earning and education are significant at $5 \%$ significance level with positive regression coefficient. This defines that with the increase in these variables, willingness to pay also increases. Whereas, the negative regression coefficient on total household member represents that the WTP decreases with the increase in total household member at $10 \%$ significance level.

Income and Education level of the respondents are found to cause significant difference in the amount of WTP. Increase in lake based income make the people responsible for the conservation of the lake. Similarly, education level of the respondent shows that they have higher awareness level on the PES mechanism and are ready to pay more compensation to the upstream land managers. Factors like age and distance from lake don't show any significance 
difference with the WTP. In the case of age, the first (20-40) age group of people were not willing to pay as they were not much concerned about the future. (40-60) age group of people were willing to pay as they feel concerned about the future generation. Whereas above 60 age group of people have less WTP due to less income. Similarly, distance from lake also doesn't matter in WTP. As compared to migrated one, the old residence are more willing to pay as they love their birth place and get more services from the lake from the very past.

Different independent variables like Education, Residency time, Income and total household member were found to be the major factors hindering WTP (KC et al., 2013). Generally in this study, age group of (20-40) are less willing to pay and then the value increases in (40-60) age group. And then WTP again decreases to the respondent of 60+ age group. Gender was also not found to be the factor affecting WTP in this study because both male and female well equally educated and are equally employed thus having similar WTP.

\section{Table 6}

\section{Multiple Linear Regression Model}

\begin{tabular}{llll}
\hline Variables & \multicolumn{2}{l}{ Regression Coefficients } & $\mathrm{t}$ \\
& \multicolumn{2}{l}{ Coefficeints } & \multicolumn{2}{l}{ Stand. Eror } & \\
\hline (Constant) & 42.820 & 105.335 & 0.407 \\
Age & 41.309 & 26.187 & 1.577 \\
Distance from lake & 5.421 & 2.356 & 1.962 \\
Time of residency & $12.201^{* *}$ & 5.635 & 2.165 \\
Total household member & $-22.545^{*}$ & 12.595 & -1.790 \\
Lake based earning & $0.005^{* *}$ & .002 & 2.120 \\
Education & $10.228^{* *}$ & 4.543 & 2.251 \\
\hline
\end{tabular}

$* * \mathrm{p}<0.05$ and $\mathrm{p}<0.1$

The model yielded the adjusted coefficient of multiple determinations (adjusted $\mathrm{R}^{2}$ ) of 0.794 suggesting that $79.4 \%$ of the total variance in the amount of WTP was explained by these explanatory variables.

\section{DISCUSSION}

In this study, Clean and silt less water was found to be the most prioritized environmental services based on the respondent's perception. This result is same with the study conducted by (Maskey, 2010; Paudel, et al., 2012) in Phewa watershed. This illustrates that the downstream communities' focuses on the Watershed Protection as they have to suffer from many trouble 
like natural disaster and sedimentation problem as these impacts will certainly bring negative impact on their occupation as well as their livelihood (Thapa et al., 2020).

Similarly, the average WTP for the protection of Phewa Lake by the respondents was estimated to be US\$17 per household per year. The finding is in line with the study conducted by Lamsal et al., (2015) in Ghodaghodi Lake, Nepal and Verma and Negandhi, (2011) in Bhoj wetland, India. Similarly, in the study conducted by Paudel, et al., (2012) people were even willing to pay more than $2 \%$ of their income (about $30 \%$ of the respondents) for watershed protection. This study identified that lack of WTP that much amount in this study could be because of less income and lack of knowledge and awareness about PES. Generally, fishing communities and agricultural communities don't seem to have awareness about PES mechanism and that is the reason that they were not willing to pay much amount though are suffering from the impacts.

The adjusted $\mathrm{R}^{2}$ (.794) shows the strength of the model used for analyzing the WTP in this study. Age and education are positively related to the WTP but not statistically significant. This finding is similar to the findings of Bhandari et al. (2016) and Bhandari et al. (2018). The positive relationship indicates that adult persons and educated persons pay more to protect lake than the youth and less educated people. It implies that conservation awareness and education programs need to be implemented with particular focus on youths. The variable lake based earning is also positively co-related with the WTP. It reveals that people having higher income are willing to contribute more to protect Lake. This finding suggest that Lake management facilitations need to be focused on creating economic opportunities that help to increase income of surrounding communities. The study conducted by Paudyal et al. (2015), Bhandari et al. (2016), and Bhandari et al. (2018) have the same finding. The household having a smaller family size and living near to lake were inclined to show more WTP, which is consistent with the finding of Bhandari et al. (2018). There is a positive correlation between family size and the requirement for goods and services from forest and lake. Therefore this relationship demonstrates a higher WTP as the family size and lake distances decreases.

\section{CONCLUSION}

The prioritized environmental service is Watershed protection as people are suffering from the sedimentation problem directly or indirectly. The upstream and downstream are willing to initiate PES mechanism in that area. So, establishment of PES schemes can be done focusing on Sedimentation problem. 
Various factors like education, income, time of residency, and total household member play a significant role in causing the variance in WTP. So, strengthening in education sector can be helpful in conserving forest and lake. Thus, PES is an emerging concept in our context; it should be replicated in Panchase area by formulating clear policies. Unplanned engineering construction of rural roads should be minimized and bioengineering structures mainly the construction of siltation dam is the utmost need of the area for controlling the impact of Sedimentation.

Awareness campaign can be done in order to increase the understanding of PES and WTP/A in both upstream and downstream level. Conceptual framework should be established on local level for providing better understanding about the subject matter. PES mechanism should be designed so simple that all the users can participate actively. Proper policy mechanism will support this PES mechanism with better assurance for the community people.

\section{REFERENCES}

Aryal, K., Bhatta, L. D., Thapa, P. S., Ranabhat, S., Neupane, N., Joshi, J., \& Shrestha, A. B. (2019). Payment for ecosystem services: Could it be sustainable financing mechanism for watershed services in Nepal. Green Finance, 1(3), 221.

Bhandari, P., Shrestha, S., Aryal, A. Shrestha, U.B. (2016). Assessment of ecosystem services indicators and stakeholder's willingness to pay for selected ecosystem services in the Chure region of Nepal. Applied Geography 69,25-34.

Bhandari, A. R., Khadka, U. R., \& Kanel, K. R. (2018). Ecosystem services in the mid-hill forest of western Nepal: A case of Panchase protected forest. Journal of Institute of Science and Technology, 23 (1), 10-17.

Bhatta, L. D., van Oort, B. E. H., Rucevska, I., \& Baral, H. (2014). Payment for ecosystem services: Possible instrument for managing ecosystem services in Nepal. International Journal of Biodiversity Science, Ecosystem Services \& Management, 10 (4), 289-299.

Costanza, R. d. G., Rudolf Sutton, Paul Van der Ploeg, Sander Anderson, Sharolyn J Kubiszewski, Ida Farber, Stephen Turner, \& Kerry, R. (2014). Changes in the global value of ecosystem services. Global Environmental Change, 26, 152-158.

Costanza R, d'Arge R, De Groot R, Farber S, Grasso M, Hannon B, Limburg K, Naeem S, O’neill RV, Paruelo J, \& Raskin R.G. (1997). The value of the world's ecosystem services and natural capital. Nature, 387 (6630), 253.

DoF. (2012). Panchase protected forest management plan department of forests. Department 
of Forest, Ministry of Forest, Nepal.

Fisher, B., Turner, R. K., \& Morling, P. (2009). Defining and classifying ecosystem services for decision making. Ecological Economics, 68(3), 643-653.

Gurung, T. B., Wagle, S. K., Bista, J. D., Joshi, P. L., Batajoo, R., Adhikari, P., \& Rai, A. K. (2005). Participatory fisheries management for livelihood improvement of fishers in Phewa Lake, Pokhara. Himalayan Journal of Sciences, 3 (5), 47-52.

Kc, B., Kandel, P. N., \& Adhikari, S. (2013). Economic valuation of ecosystem services in protected areas: A case study from Nepal. Banko Janakari, 23 (1), 42-50.

Lamsal, P., Pant, K. P., Kumar, L., \& Atreya, K. (2015). Sustainable livelihoods through conservation of wetland resources: A case of economic benefits from Ghodaghodi Lake, western Nepal. Ecology and Society, 20 (1).

Maskey, D. (2010). Analyzing potential of payment for environmental services in Phewa watershed. Pokhara. [A thesis submitted for the partial fulfillment of requirement for the Degree of Masters of Science in Forestry], Tribhuvan University, Institute of Forestry, Pokhara campus, Pokhara.

MEA. (2005). Millennium ecosystem assessment. Ecosystems and human well-being: Biodiversity synthesis. Washington DC: World Resources Institute, Washington, DC.

Paudyal, K., Baral, H., Burkhard, B., Bhandari, S.P., \& Keenan, R.J. (2015). Participatory assessment and mapping of ecosystem services is a data-poor region: Case study of community-managed forests in central Nepal. Ecosystem Services 13 (81-92).

Paudyal, K., Baral, H., Putzel, L., Bhandari, S., \& Keenan, R. J. (2017). Change in land use and ecosystem services delivery from community-based forest landscape restoration in the Phewa Lake watershed, Nepal. International Forestry Review, 19 (4), 88-101.

Paudyal, K., Baral, H., \& Keenan, R. J. (2018). Assessing social values of ecosystem services in the Phewa Lake Watershed, Nepal. Forest Policy and Economics, 90, 67-81.

Poudel, D, \& Khanal, R. (2012). Payment for ecosystem services (PES) schemes for conserving Sardu Watershed Nepal: Existing practices and future prospecs technical working paper. International Union for Conservation of Nature [IUCN] Nepal office.

Paudel, K., Ranjit, M. \& Bajracharya, R. (2012). An assessment of mechanism of payment of ecosystem services of Phewa Watershed.

Suwal, R. N., Bhuju, U. R., Tiwari, K. R., \& Pokhrel, R. K. (2013). Preliminary identification of essential and desirable ecosystem services in the Panchase Area of Nepal: A report on environmental camps for conservation awareness (ECCA). United Nations Environment 


\section{Program (UNEP).}

Verma, M., \& Negandhi, D. (2011). Valuing ecosystem services of wetlands: A tool for effective policy formulation and poverty alleviation. Hydrological Sciences Journal, 56 (8), 1622-1639.

Vuillez, C., Tonini, M., Sudmeier-Rieux, K., Devkota, S., Derron, M. H., \& Jaboyedoff, M. (2018). Land use changes, landslides and roads in the Phewa Watershed, western Nepal from 1979 to 2016 Applied Geography, 94, 30-40.

Zhou, C., \& Li, G.P., (2015). The Influencing factors for willingness to pay of payment for watershed services: A case of the water receiving area of Zhengzhou city of the middle route project of the South-North water transfer project. Econ. Geogr, 6, pp.38-46. 